\title{
PENGALAMAN PERAWAT DALAM PENGGUNAAN REKAM MEDIS ELEKTRONIK DI RUMAH SAKIT PANTI RINI YOGYAKARTA
}

\author{
Ernest Novema Dhamar ${ }^{1}$, Margareta Hesti Rahayu ${ }^{2}$ \\ ${ }^{1}$ STIKes Panti Rapih Yogyakarta, ernestnovemadhamar@gmail.com \\ ${ }^{2}$ STIKes Panti Rapih Yogyakarta, margaretha.hestirahayu@stikespantirapih.ac.id
}

\begin{abstract}
ABSTRAK
Latar Belakang: Dokumentasi keperawatan melalui rekam medis elektronik diharapkan mampu memberikan kemudahan bagi perawat.

Tujuan:Tujuan penelitian ini adalah untuk mendapatkan gambaran pengalaman perawat dalam menggunakan rekam medis elektronik.

Metode: Penelitian ini menggunakan metode kualitatif, metode pengumpulan data dalam penelitian ini menggunakan teknik purposive sampling. Penelitian dilakukan di Rumah Sakit Panti Rini Yogyakarta. Penelitian ini dilakukan pada bulan Mei 2020. Sample yang digunakan yaitu adalah 5 perawat pelaksana dan 1 kepala ruang yang ada di ruang rawat inap.

Hasil: Hasil penelitian didapatkan ada 4 tema yaitu: penggunaan rekam medis elektronik memberikan kemudahan, faktor pendukung penggunaan rekan medis elektronik, hambatan dalam penggunaan rekam medis elektronik dan harapan perawat dalam penggunaan rekam medis elektronik.

Simpulan: rumah sakit perlu meningkatkan sarana dan prasarana agar system yang tersedia mampu mengakomodir kebutuhan dokumentasi asuhan keperawatan secara eletronik

Kata kunci : Perawat, rekam medis, elektronik
\end{abstract}




\begin{abstract}
Background: Nursing documentation through electronic medical records is expected to provide convenience for nurses.

Purpose: explore nurses' experiences in using electronic medical records.

Method: this study was a qualitative research, used purposive sampling technique. The research was conducted at Panti Rini Hospital Yogyakarta and conducted in May 2020 and interviewed 5 nurses and 1 head of the ward in the inpatient ward.

Result: this study found 4 themes: 1) the use of electronic medical records to provide convenience, 2) supporting factors for the use of electronic medical partners, 3) obstacles in the use of electronic medical records 4) the expectations of nurses in using electronic medical records.

Conclusion: the hospital needs to improve facilities and infrastructure so that the available system is able to accommodate the need for electronic nursing care documentation.
\end{abstract}

Key word's: nurse, medical records, electronic.

Latar Belakang

Revolusi Industri telah

mengubah cara kerja manusia dari penggunaan manual menjadi

otomatisasi atau digitalisasi (Suwardana,

2018). Rekam medis elekronik merupakan inovasi di bidang Kesehatan dengan mengembangkan teknologi

digital (Tjandrawinata, 2016).

Perkembangan teknologi tersebut memberi dampak dalam melakukan dokumentasi keperawatan bagi perawat.

Perawat memiliki peran yang penting dalam akuisisi, evaluasi dan penerapan rekam medis elektronik.
Adanya rekam medis elektronik memungin dokter dan perawat untuk dapat mengakses data Kesehatan pasien dengan mudah sehingga dapat mengambil keputusan dengan cepat (Kamau, 2015)

$$
\text { Beberapa hasil penelitian }
$$
menunjukkan bahwa dokumentasi keperawatan masih menjadi permasalahan. Sebuah penelitian di salah satu rumah sakit di Iran menunjukkan bahwa $85,9 \%$ perawat memiliki pengetahuan yang terbatas dalam hal dokumentasi keperawatan sehingga dokumentasi keperawatan 
yang dilakukan tidak lengkap (Jasemi, et.al, 2012). Dokumentasi keperawatan yang dilakukan perawat dalam memberikan obat juga masih banyak yang belum lengkap. Sebagian besar rekam medis $(88,9 \%)$ tidak terdokumentasi efek samping obat dan lebih dari separuh rekam medis $(66,7 \%)$ tidak memiliki dokumentasi lengkap efek pengobatan (Rahayu, 2019).

Penggunaan dokumentasi secara elektronik diharapkan mampu mengatasi permasalahan dalam dokumentasi keperawatan yang selama ini dilakukan dengan cara menuliskan secara langsung pada lembar kertas, namun dari hasil penelitian di sebuah rumah sakit di Iran juga menunjukkan bahwa dokumentasi keperawatan dengan menggunakan system informasi keperawatan masih kurang baik (Ahmadi \& Habibi, 2010). Di Indonesia, penelitian terkait kelengkaoan dokumetasi keperawatan secara elektronik masih sangat terbatas, hal ini karena belum banyaknya rumah sakit yang menggunakan rekam medis elektronik.

\begin{tabular}{|c|c|c|}
\hline Rumah & Sakit & Panti \\
\hline Yogyakarta & telah & menerapkan \\
\hline
\end{tabular}
menggunakan rekam medis elektronik, tetapi sejauh ini belum pernah dilakukan evaluasi terhadap penggunaan dokumentasi tersebut, maka peneliti akan melihat lebih lanjut tentang pengalaman perawat dalam penggunaan rekam medis elektronik.

\section{METODE PENELITIAN}

Penelitian ini merupakan penelitian kualitatif. Pengambilan sampel ini dilakukan dengan teknik purposive sampling. Partisipan dalam penelitian ini adalah 5 orang perawat pelaksana yang ada di ruang rawat inap Rumah Sakit Panti Rini Yogyakarta. Kegiatan penelitian dilakukan dengan melakukan perijinan dan memberikan informed consent pada partisipan yang terpilih dalam penelitian ini. Proses pengumpulan data dilakukan pada bulan Mei 2020 dengan melakukan wawancara. Wawancara dilakukan secara virtual dengan menggunakan telepon selular (handphone), hal ini disebabkan karena kondisi yang tidak memungkinkan untuk melakukan pengambilan data secara langsung ke rumah sakit akibat adanya Pandemi Covid-19. Triangulasi data dilakukan dengan cara melakukan wawancara pada kepala ruang di ruang rawat inap. 
Proses analisis ini melalui beberapa langkah: yaitu dimulai dengan melakukan wawancara untuk mendapatkan data, kemudian membuat transkrip. Peneliti kemudian mencari pernyataan mengenai bagaimana individu-individu mengalami topic tersebut dan membuat daftar dari pernyataan-pernyataan tersebut untuk menarik kesimpulan. Pernyataan kemudian dikelompokan kedalam unitunit atau tema. Kemudian peneliti membuat kesimpulan berdasarkan deskripsinya sendiri dari tema yang didapat, dan dikaitkan dengan hasil wawancara yang di dapat.

\section{HASIL DAN PEMBAHASAN}

Karakteristik Partisipan

Tabel 1

Karakteristik Partisipan

\begin{tabular}{|c|c|c|c|}
\hline Partisipan & Pendidikan & $\begin{array}{l}\text { Masa } \\
\text { Kerja }\end{array}$ & Status \\
\hline 1 & DIII Kep & $\begin{array}{l}19 \text { tahun } \\
16 \text { tahun }\end{array}$ & $\begin{array}{l}\text { Perawat } \\
\text { Pelaksana }\end{array}$ \\
\hline 2 & DIII Kep & 9 tahun & $\begin{array}{c}\text { Perawat } \\
\text { Pelaksana }\end{array}$ \\
\hline 3 & DIII Kep & 7 tahun & $\begin{array}{c}\text { Perawat } \\
\text { Pelaksana }\end{array}$ \\
\hline 4 & DIII Kep & 3 tahun & $\begin{array}{l}\text { Perawat } \\
\text { Pelaksana }\end{array}$ \\
\hline 5 & DIII Kep & 25 tahun & $\begin{array}{l}\text { Perawat } \\
\text { Pelaksana }\end{array}$ \\
\hline 6 & DIII Kep & & $\begin{array}{l}\text { Kepala } \\
\text { Ruang }\end{array}$ \\
\hline
\end{tabular}

Sumber : Data Primer

Hasil penelitian ini mendapatkan

4 tema yaitu: penggunaan rekam medis elektronik memberikan kemudahan, faktor pendukung penggunaan rekan medis elektronik, hambatan dalam penggunaan rekam medis elektronik dan harapan perawat dalam penggunaan rekam medis elektronik.

Tema 1: penggunaan rekam medis elektronik memberikan kemudahan. Penggunaan rekam medis elektronik di Rumah Sakit Panti Rini saat ini baru digunakan untuk mendokumentasikan data pasien, belum digunakan untuk mendokumentasikan asuhan keperawatan dikarenakan system yang akan digunakan untuk melakukan dokumentasi asuhan keperawatan belum siap namun demikian hal ini dirasakan memberi kemudahan bagi perawat untuk mencari data pasien yang dibutuhkan.

Partisipan 1: "Menggunakan rekam medic elektronik itu jauh lebih simple ya, jadi kita lebih mudah mengaksesnya, ntah itu rekam medic dari rawat jalan nanti di teruskan ke rawat inap jauh lebih mudah." ."ebih cepat untuk mencari data-datanya itu sendiri". "Asuhan keperawatan khususnya di ranap RS panti Rini belum menggunakan RME dalam penulisannya dek. Jadi untuk pengalamannya belum ada."

Partisipan 5: "Yang dirasakan lebih gampang atau mudah gitu mungkin ya. J adi mempermudah dan mempercepat" . "Dalam melakukan asuhan keperawatan yang meliputi pengkajian sampai dengan evaluasi itu dilakukan 
di kertas dek, soalnya belum tersedia sistemnya dek"

$$
\text { Pengunaan rekam juga }
$$

memberikan kemudahan untuk membaca tulisan di komputer dibandingkan jika menggunakan tulisan tangan, lebih hemat karena tidak banyak membutuhkan kertas, tidak banyak menulis dan bisa terhubung ke beberapa bagian dengan mudah.

Partisipan 2: "Kalau manfaatnya secara keseluruhan kita bisa berkomunikasi dengan unit yang lain dengan mudah, bisa langsung melihat di SIMRS di rekam medis Rumah Sakit, bisa ngelink kemana-mana.". "Untuk penyajiannya datanya sendiri kan secara elektronik kan berarti mudah dibaca, tidak banyak tulisan. Kalau manual kan tulisantulisan kan susah untuk dibaca (itu apa artinya) gitu kan. Tapi kalau di elektronik itu mudah semuanya. Jadi lebih jelas". "Kalau di ranap belum melakukan pendokumentasian asuhan keperawatan. Baik itu mulai dari pengkajian hingga evaluasi."

Partisipan 3: "Terus yang pasti hemat juga, maksudnya kalau pake kertas juga kan dulu banyak banget kan, dek. Kalau yang sekarang ini bisa lebih hemat. Hemat lingkungan juga sih". "Sejauh ini untuk pengalaman melakukan asuhan keperawatan melalui rekam medis elektronik belum dek".

Partisipan 4: "Untuk pengalamannya, kita jadi lebih cepat melakukan dokumentasi, karna dokumentasi di sistem, jadi tidak membutuhkan banyak menulis". "Penggunaan rekam medis ini lebih ke mencari data-data pasien dek, kemudian permintaan rogent, permintaan lab sudah menggunakan system. Jadi pengalam an sih saya belum pernah sih dek untuk asuhan keperawatan secara elektronik dek".

Hal yang sama juga disampaikan oleh kepala ruang rawat inap bahwa adanya rekam medis elektronik ini memberikan kemudahan terlebih adanya fasilitas jaringan dan computer yang tersedia di setiap nurse station.

Partisipan 6: Kebutuhan sarana dan prasarana sudah membantu sih dek misalkan ketersediaan jaringannya untuk ngelink-ngelink itu sudah baik dan lebih dipermudahkan dek. Untuk komputer juga sudah disediakan di setiap Nurse station nya dek jadi yang sudah mendukung dan membantu untuk sarana dan prasarananya dan dapat berjalan dengan lancar sih untuk saat ini.

Persepsi perawat terhadap penerimaan teknologi rekam medis elektronik, menunjukkan bahwa penggunaan rekam medis elektronik mempermudah

proses pendokumentasian asuhan keperawatan karena para perawat tidak perlu menulis banyak dan juga memudahkan perawat dalam mengakses informasi kesehatan pasien dengan cepat sehingga mempermudah proses asuhan keperawatan dan mempercepat 
pekerjaan perawat (Risdianty \&

Wijayanti, (2019). Perawat setuju bahwa pengguanaan rekam medis elektronik mengurangi penggunaan kertas. Proses penginputan, penyimpanan, pencarian, pembuatan laporan dan koordinasi antar unit dan pengiriman data menjadi lebih efektif (Irawan, 2019).

Ada empat faktor operasional yang didapat dengan adanya rekam medis elektronik yaitu adanya kecepatan penyelesaian pekerjaan, akurasi (khususnya akurasi data), faktor efisiensi, faktor yang keempat adalah kemudahan dalam pelaporan data (Dwijosusilo \& Sarni, 2018). Kamau (2015) menyatakan bahwa penggunaan rekam medis elektronik dapat memperbaiki kualitas perawatan, efisien waktu dan menekan biaya operasional.

Tema 2: Faktor pendukung penggunaan rekam medis elektronik

Ketersediaan sarana dan prasarana yang meliputi: komputer, labtop di setiap unit, dan jaringan internet, sumber daya manusia (SDM) yang memiliki motivasi tinggi untuk belajar, kebijakan manajemen rumah sakit, staf IT dan pelatihan-pelatihan menjadi faktor pendukung dalam penggunaan rekam medis elektronik.
Partisipan 2: "Kalau untuk computer sudah cukup, sudah di beberapa unit. Dibeberapa kantornya sudah ada 2 komputer - 2 komputer". "sumber daya manusia (SDM)nya mau untuk berkembang, mau untuk belajar dari sistem itu sendiri, mau mengikuti semua perubahan-perubahan yang ada, sama kita sesuai dengan teori yang berkembang juga".

Partisipan 3: " Di Rumah Sakit ini ada tim khusus, memang tidak 24 jam. Tetapi kita bisa komunikasi saat dia dirumah, jadi programnya dia sudah terkoneksi di rumahnya dia. Jadi misalkan kita ada kesulitan atau ada gangguan gitu bisa langsung otomatis teratasi gitu"." Untuk pelatihan khususnya memang ada, seperti sosialisasi jadi kalau misalkan setiap ada program baru apa-apa, pasti dari unit yang terkait pasti akan melakukan sosialisasi

Partisipan 4: U ntuk jaringannya sudah lumayan bagus ini, hanya saja masih sempat lambat-lambat gitu. Tapi sekarang sudah lumayan bagus sih, tidak ada kendala lah kalau untuk sarana dan prasarana nya ini

Partisipan 6: Dari kebijakan managemen Rumah Sakit Panti Rini sih bagus dek selalu mendukung.

SDM mau mengikuti perubahan dan tetap mau belajar, yang pasti saling mendukung satu sama lain dek.

Penerapan rekam medis elektronik didukung oleh fasilitas yang memadai, pimpinan, dan manajemen rumah sakit yang selalu memberikan support (Risdianty \& Wijayanti, 2019). Fasilitas yang memadai mempengaruhi 
sikap positif dari pengguna sistem teknologi (Adriani, 2017). Efektivitas waktu pelaksanaan dokumentasi asuhan keperawatan dipengaruhi oleh kemampuan sumber daya manusia dalam melakukan dokumentasi elektronik (Nurjannah, 2017).

Tema 3: Hambatan penggunaan rekam medis elektronik

Ketersediaan sarana dan prasarana di runah sakit yang saat ini sudah dirasakan memadai namun demikian masih ada hambatan yang dirasakan oleh perawat yaitu; Jaringan internet yang kadang lambat, Komputer yang kadang mengalami kendala dan jumlah computer yang dirasa kurang meskipun sudah tersedia di setiap unit.

Sistem yang belum tersedia untuk melakukan dokumentasi asuhan keperawatan secara elektronik juga mejadi penghambat yang dirasakan oleh perawat.

Partisipan 1: "Ada waktu-waktu tertentu memang koneksinya menjadi agak lambat dan susah, karna kan internet nya sendiri, disini jaringannya belum begitu kuat" "Hambatannya sejauh ini mungkin karna manajemen RS yang masih berproses dengan teknologi ini sihh dek. Kemudian diliat dari komputernya juga kurang di ranap ini".

Partisipan 3: "Internet memang kadang-kadang ada posisi yang memang turun, jadi ada beberapa saat yang memang kadang juga loadingnya lama". "Dilihat dari hambatan yang ada sih itu terbatas dari jumlah kumputer yang bisa digunakan mungkin unruk melakukam pendokumentasian asuhan keperawatan secara elektronik".

Ada hal lain yang ditambahkan oleh kepala ruang sebagai hambatan dalam penggunaan rekam medis elektronik adalah perawat dan staf Teknologi Informasi (IT) belum memiliki persamaan persepsi terkait dengan tampilan pada rekam medis elektronik, penyajian data yang dimiliki juga belum baku dan masih sederhana. Hal ini dipahami dan masih membutuhkan banyak perbaikan.

Partisipan 6: kendalanya ada di tampilan rekam medisnya dek, misalkan dari segi perawatnya maunya begini tetapi dari segi IT nya maunya begitu, jadi belum satu persepsi antara perawat dengan bagian IT nya. Kemudian untuk setiap item-item nya. Untuk penyajian datanya kita masih disarankan oleh akreditasi, RS Panti Rini masih belum terlalu simple dan belum baku, dikarnakan ini masih berproses dek jadi masih banyak yang harus dibenahi sebenrnya.

Adanya error terhadap sistem menjadi hal yang menakutkan bagi petugas Kesehatan. Sistem error dianggap dapat menganggu proses pelayanan yang sedang berlangsung 
dimana data harus segera dimasukkan (Rosyada, dkk (2016). Kurangnya pengetahuan untuk mengatasi kesalahan yang terjadi dalam rekam medis elektronik, dan kurangnya kemampuan dalam bidang IT menyebabkan rekam medis elektronik menjadi sulit digunakan dan menjadi hambatan dalam penggunaan rekam medis elektronik (Purwandi, 2017).

Ada beberapa faktor lainnya yang menjadi penghambat dalam pengunaan rekam medis elektronik yaitu: faktor finansial, faktor Sumber Daya Manusia (SDM), faktor proses perubahan, faktor psikologi, faktor legal, faktor waktu, faktor organisasi, dan tren Teknologi Informasi Komputer (TIK) (Wicaksono, 2017). Dokumentasi keperawatan merupakan indikator yang signifikan untuk menunjukkan kualitas perawatan. Kualitas dokumentasi keperawatan, kurangnya pengetahuan dan keterampilan dalam proses keperawatan menjadi masalah dalam dokumentasi keperawatan secara elektronik

(Akhu Zaheya,

Al Maaitah, \& Bany, 2018).

Tema 4: harapan perawat dalam penggunaan rekam medis elektronik.

Perawat berharap bahwa rekam medis elektronik dapat dimanfaatkan untuk dokumentasi asuhan keperawatan, dan semua sistem terintegrasi.

Partisipan 4 : "Harapannya sih ya itu tadi sih. Semuanya dokumentasi itu lewat komputerisasi. Seperti mulai dari awal yang kayak dari pengkajian, diagnose, perencanaan, tindakan itu sudah masuk dalam sistem komputerisasi. Dan tidak terlalu banyak menulis.

Partisipan 5: "Pengennya sih semua masuk ke elektronik dek termasuk dalam pendokumen asuhan keperawatannya juga, mulai dari pengkajian hingga evaluasi menggunakan sistem dek".

Partisipan 6: Harapannya semua dapat terintegrasi, jadi harapannya misal pasien datang dari poli klinik kemudian pengkajian yang sudah dilakukan oleh perawat poli langsung ngelink ke perawat

Penggunaan rekam medis dalam dokumentasi asuhan keperawatan memberikan kemudahan dalam melakukan pekerjaan (98\%) (Risdianty \& Wijayanti, 2019).

Minat dalam penggunaan rekam medis elektronik yang baik dapat membantu perawat dan tenaga medis lainnya dalam pekerjaannya seperti mempercepat dan mempermudah pekerjaan. Apabila sistem rekam medis elektronik berjalan dengan maksimal dan masalah-masalah yang sering terjadi dapat diatasi maka rekam medis 
elektronik dapat membantu perawat dalam menyelesaikan pekerjaannya (Purwandi, 2017).

\section{KESIMPULAN DAN SARAN}

Kesimpulan

Kemudahan dalam penggunaan rekam medis bagi perawat adalah memudahkan perawat untuk mencari data pasien yang dibutuhkan, kemudahan untuk membaca tulisan, lebih hemat karena tidak banyak membutuhkan kertas, tidak banyak menulis dan bisa terhubung ke beberapa bagian dengan mudah.

Faktor pendukung dalam penggunaan rekam medis adalah ketersediaan sarana dan prasarana, sumber daya manusia (SDM) yang memiliki motivasi tinggi untuk belajar, kebijakan manajemen rumah sakit, staf IT. Hambatan dalam penggunaan rekam medis elektronik adalah Jaringan internet yang kadang lambat, Komputer yang kadang mengalami kendala dan jumlah komputer yang dirasa kurang serta belum tersedianya system untuk melakukan dokumentasi asuhan keperawatan, serta perawat dan IT belum memiliki pehamanan yang sama terkait tampilan rekam medis elektronik.
Saran

Rumah Sakit dapat meningkatkan fasilitas yang sudah ada dengan meningkatan kapasitas jaringan internet, menambah jumlah komputer di setiap unit. Rumah sakit juga perlu mengambil kebijakan dan memfasilitasi staf IT dan perawat sehingga dapat menemukan tampilan yang tepat untuk rekam medis elektronik yang digunakan dan menyiapkan sistem yang tepat supaya bisa memfasilitasi kebutuhan untuk melakukan dokumentasi asuhan keperawatan dalam rekam medsi elektronik.

\section{DAFTAR PUSTAKA}

Ahmadi, M., \& Habibi, K. M. (2010). Nursing information systems in Iran. Hakim research Journal Fall 2010, Volume 13, Number 3; Page(s) 185 To 191.

Akhu Zaheya, L., Al Maaitah, R., \& Bany Hani, S. (2018). Quality of nursing documentation: Paper based health records versus electronic based health records. Journal of clinical nursing, 27(3-4), e578-e589.

Andriani, R., et all. (2017). Analisis Kesuksesan Implementasi Rekam Medis Elektronik Di RS Universitas Gadjah Mada. urnal Sistem Informasi, 95.

Dwijosusilo., dan Sarni. (2018). Peranan Rekam Medis Elektronik Terhadap Sistem 
Informasi Manajemen Rumah Sakit di Rumah Sakit Umum Haji Surabaya. 73.

Irawan, I. (2019). Evaluasi penerapan sistem rekam medik elektronik berdasarkan benefit realization plan Rumah Sakit Islam (Rsi) Jemursari Surabaya, http://repository.unusa.ac.id/535 9/

Jasemi, M., Zamanzadeh, V., Rahmani, A., Mohajjel, A., \& Alsadathoseini, F. (2012). Knowledge and practice of Tabriz teaching hospitals' nurses regarding nursing documentation. Thrita, 2(2), 133-138.3-4.

Kamau, N. (2015). Electronic Health Documentation and Its Impact on Nurses Routine Practices. Laurea University of Appiled Science

Nurjanah, S. (2017). Analisis Beban Kerja Tenaga Perawat di Instalasi Rawat Inap Rumah Sakit Umun Daerah (RSUD) Kota Kendari Tahun 2016. (J urnal IImiah Mahasiswa Kesehatan M asyarakat), 2(5).

Purwandi. (2017). Evaluasi Penerimaan Penerapan Rekam Medis Elektronik Di Unit Rawat Jalan Rumah Sakit http://repository.umy.ac.id/bitst ream/handle/123456789/22062/ 12B.\%20NASKAH\%20PUBLI KASI\%20INDONESIA.pdf?se quence $=12 \&$ isAllowed $=\mathrm{y}$

Rahayu , M. H. (2019). Nursing Practice towards Pediatric Medication Process in Yogyakarta's Private Hospital Indonesia . KnE Life Sciences, 4(13), 550-557. https://doi.org/10.18502/kls.v4i1 3.5305

Risdianty, N., \& Wijayanti, C. D. (2019). Evaluasi Penerimaan Sistem Teknologi Rekam Medik Elektronik Dalam Keperawatan. Carolus Jurnal of Nursing, Vol. 2 No. 1, 34.

Rosyada, dkk.(2016). Persepsi Petugas Kesehatan Terhadap Peran Rekam Medis Elektronik Sebagai Pendukung Manajemen Pelayanan Kesehatan di Rumah Sakit Panti Rapih Jogjakarta: Journal of Information Systems for Public Health Vol. 1 No. 2

Suwardana, H. (2018). Revolusi Industri 4. 0 Berbasis Revolusi Mental . Jurnal IImiah Teknik dan Manajemen Industri , Vol.1, No.2, 103.

Tjandrawinata, R. R. (2016, Februari). Industri 4.0: Revolusi Industri Abad Ini Dan Pengaruhnya Pada Bidang Kesehatan Dan Bioteknologi. Working Paper from Dexa Medica Group, 2.

Wicaksono, A. P. (2017). Faktor Penghambat Implementasi dan Penggunaan Rekam Medis Elektronik di Kabupaten Banyumas (Doctoral dissertation, Universitas Islam Indonesia). 